\title{
RESERVES FOR REDUCTION OF LABOR CAPACITY OF HOTEL AND RESTAURANT PRODUCT AND THEIR EFFECTIVE USE IN THE ENTERPRISE PERSONNEL MANAGEMENT SYSTEM

\author{
РЕЗЕРВИ ЗМЕНШЕННЯ ТРУДОМІСТКОСТІ ГОТЕЛЬНО-РЕСТОРАННОГО \\ ПРОДУКТУ ТА ЇХ ЕФЕКТИВНЕ ВИКОРИСТАННЯ \\ В СИСТЕМІ МЕНЕДЖМЕНТУ ПЕРСОНАЛУ ПІДПРИЄМСТВА
}

UDC 658:338.2:005

DOI: https://doi.org/10.32843/infrastruct47-23

\section{Tsviliy Sergiy}

Candidate of Economic Sciences,

Associate Professor,

Senior Lecturer at Department of Tourism,

Hotel and Restaurant Business

National University

"Zaporizhzhia Polytechnic"

Gurova Darya

Candidate of Geographical Sciences,

Associate Professor,

Senior Lecturer at Department of Tourism, Hotel and Restaurant Business

National University

"Zaporizhzhia Polytechnic"

Bulatov Sergiy

Senior Instructor at Department of

Tourism, Hotel and Restaurant Business

National University

"Zaporizhzhia Polytechnic"
The article discusses the ways to search for reserves in order to reduce the labor intensity of a hotel and restaurant product and their effective use in the personnel management system of an enterprise. The factors that influence the change in the labor intensity of the hotel and restaurant product through their comprehensive analysis have been determined. The direction of the analysis of changes in the labor intensity of the program for the production of the final product is structured. The groups of reserves for increasing labor productivity are identified on the basis of monitoring the indicators of the labor intensity of a particular product. It is proposed to divide the factors of influence on the formation of reserves for reducing the labor intensity of a hotel and restaurant product into groups: an increase in the technological level of the product; complex automation of product production; improvement of technological processes; improving the organization of work; improving the management and organization of product production.

Key words: enterprise, hotel and restaurant product, management system, labor intensity, personnel, service technology.

B cтатье рассмотрены пути поиска резервов снижения трудоемкости гостинично- ресторанного продукта и эфрфрективное их использование в системе менеджмента персонала предприятия. Определены фракторы, которые оказывают влияние на изменение трудоемкости гостинично-ресторанного продукта посредством проведения комплексного их анализа. Структурировано направление анализа изменения трудоемкости программы производства конечного продукта. Выделены группы резервов повышения производительности труда на основе мониторинга и анализа показателей трудоемкости конкретного продукта. Предложено разделение фракторов влияния на формирование резервов снижения трудоемкости гостинично-ресторанного продукта на группы: рост технологического уровня продукта; комплексная автоматизация производства продукта; совершенствование технологических процессов; совершенствование организации труда; совершенствование управления и организации производства продукта.

Ключевые слова: предприятие, система менеджмента, трудоемкость, персонал, технология обслуживания, гостиничноресторанный продукт.

В статті розглянуто шляхи пошуку резервів зниження трудомісткості готельно-ресторанного продукту та їх ефрективне використання в системі менеджменту персоналу підприємства. Доведено, що персонал готельно-ресторанних підприємств $є$ базовим елементом в концепції обслуговування, і саме тому, зростання ефективності використання трудових ресурсів має розглядатися з позиції системи факторів взаємодії працівника із техніко-технологічними засобами. Визначено фрактори, які здійснюють вплив на зміну трудомісткості готельно-ресторанного продукту за допомогою проведення комплексного їх аналізу. Структуровано напрямки аналізу зміни трудомісткості програми виробництва кінцевого продукту: конструктивні, технологічні, вдосконалення організації виробництва і праці, зміна системи кооперації, впровадження технологічно обгрунтованих норм, перегляд застарілих і помилково встановлених норм. Виокремлено три групи резервів підвищення продуктивності праці на основі моніторингу й аналізу показників трудомісткості конкретного продукту: резерви зниження трудомісткості продукту; резерви використання фонду робочого часу; резерви раціонального використання персоналу компанії. Запропоновано поділ фракторів впливу на фоомування резервів зниження трудомісткості готельно-ресторанного продукту на групи: зростання технологічного рівня продукту; комплексна автоматизація виробництва продукту; вдосконалення технологічних процесів; вдосконалення організації праці; вдосконалення управління і організації виробництва продукту. Зроблено висновок, що тільки при чіткій взаємодії технологічних, економічних, маркетингових підрозділів компанії, вмілій комбінації адміністративного впливу, матеріальних і моральних стимулів для персоналу резерви зниження трудомісткості готельно-ресторанного продукту перетворюються в реальну оптимізацію і економію витрат людської праці. Сформульовано напрямок подальших наукових досліджень: діджиталізація бізнесу готельно-ресторанних підприємств є критично необхідною умовою безпекового існування в короткій перспективі.

Ключові слова: підприємство, готельно-ресторанний продукт, система менеджменту, трудомісткість, персонал, технологія обслуговування.

Formulation of the problem. In today's business, which is characterized by many global challenges, crises, their consequences, tough competition can withstand only those hotels and restaurants that have retained the "old" customer base, and are constantly looking for rational solutions to attract new customers. The staff of the hotel and restaurant enterprises is a basic element in the concept of service. The timeliness of the study of personnel management problems of hotel and restaurant organizations is explained by the increased demands of customers for services in this business in the context of the COVID-19 pandemic. Undoubtedly, the quality of hotel and restaurant services depends entirely on the skill and consciousness of the employees. That is, human resource management is one of the important functions in the personnel management system of a hotel or restaurant. In a coronavirus economy, the state of the hotel and restaurant services is characterized as a crisis with low productivity, loss of prestige, disproportionate pay and, accordingly, "aging" of labor resources. The loss of the level of qualification of domestic labor resources in terms of the level of informativeness and manufacturability of hotel and 
restaurant products, as well as the outdated technical and technological base of most companies in this area of business determine low productivity and high complexity of the work performed. The increase in the efficiency of labor resources should be considered from the standpoint of a system of factors of employee interaction with technical and technological means. Improving the level of quality of such interaction, providing labor with modern technical and technological means, training of employees is an urgent scientific and practical task.

At the same time, despite the constant scientific interest in the problems of development and efficiency of production of hotel and restaurant product, it should be noted that the scientific community does not pay enough attention to the study of comprehensive assessment of technical and organizational working conditions. With the current rapid global changes in economic conditions of business enterprises in the hotel and restaurant industry, their further development in the post-coronavirus era should be based on an innovative mechanism of personnel management and a fundamentally new approach to combine labor potential with existing characteristics of technical and technological support optimally. The basis of such a mechanism should be modern methods of assessing the technical and technological base of the hotel and restaurant enterprises. That is why the direction of this study is relevant in today's conditions.

Analysis of recent research and publications. Fundamental studies of the essence of the human factor of social production contain scientific works of representatives of the school of quantitative economics, such as W. Petty, D. Mile, A. Kettle, A. Lavoisier, where an attempt to value a person and his or her useful properties was made $[1 ; 3 ; 5]$. Representatives of the classical school, like A. Smith, D. Ricardo, K. Marx, F. Engels, N. Senior, G. McLeod, I. Fischer and others, made a significant contribution to the disclosure of the role of the human factor in the development of the product production. These scientists first formulated the concept of "labor", which is carried by man, and gave it the status of a specific component of fixed capital, and when considering the process of labor development focused on the accumulation and improvement of human abilities to work [2]. Further development of theories of the human factor of social production is embodied in the development of theories of the personnel management, namely: theories of needs (theories of needs by A. Maslow, C. Alfred; the two-factor theory by F. Herzberg; the theory of needs in the achievements of D. McClelland and others) [4].

The increase in scientific interest of domestic researchers in cost-saving systems is caused primarily by the growing impact of global negative factors on the human capital market and the importance of the enterprise management in a constant crisis in global and national economic systems. The issue of labor use is relevant due to the fact that almost half of production costs in the total cost of production are labor costs. Scientists, in general, have significant achievements in this direction and have made some contribution to the development of theoretical provisions of the methodology for estimating the complexity of the final product. Thus, ways to reduce labor intensity in the system of cost savings of product production are analyzed by foreign (B. Henkin, G. Schlesinger, M. Hrachev, V. Liechtenstein, A. Lubinetskyi) and domestic scientists (D. Bohinya, B. Ihumnov, V. Lahutin, O. Umanskyi, I. Bondar) [6; 7].

Some issues of personnel management in the hotel and restaurant business and regulation of labor intensity of the product in cost management of firms of this type are considered in the works of scientists: Zaitseva V.M., Kuklina T.S., Kornienko O.M., Vindyuka A.V., Memotenko D.Y., others [8-10].

However, acknowledging the achievements of many researchers, it should be noted that without sufficient attention of scientists there have been some problematic aspects in the study of the specifics of the hotel and restaurant product and labor intensity. In particular, when recognizing the need to reduce human labor costs, the issue of finding reserves to reduce labor intensity and their effective use is unresolved. This confirms the relevance and timeliness of the chosen topic in the face of the negative factors of the coronavirus economy.

Setting objectives. The aim of the article is to find reserves to reduce the complexity of the hotel and restaurant product and their effective use in the personnel management system of the enterprise on the basis of generalization of theoretical experience, monitoring methods of assessing the technical and technological base of hotel and restaurant enterprises.

Presentation of the main research material. The provision of hotel and restaurant services or the production of the final product in the hotel and restaurant industry has specific features that can be described as follows: frequent change of the nomenclature of products and services for the consumer (1); constant process of mastering the technology of providing new services (2); repeated reconfiguration of equipment for a limited period of time in order to release a new product in the restaurant sector (3); production of a product that is in a wide range of quality (4); a high share of skilled labor (5). The production of hotel and restaurant product is quite specific both in terms of organization and in terms of cost. In this case, one of the main tasks is to determine at the stage of deciding on the inclusion of the product in the range of profitability of its manufacture or provision, which, in turn, requires a fairly accurate calculation of its complexity (time norms). For identifying the factors that influence the change in the complexity of the hotel and restaurant product, it is appropriate to conduct a comprehensive analysis of its complexity, the object 
of which is all regulatory, planning and reporting documentation of the company (information) (Figure 1). Thus, at the first stage of the analysis, it is important to assess the implementation of the task of saving labor costs in terms of the program of production of hotel and restaurant product for the company, as a whole, and in terms of sites. Further, at the following stages of the analysis of reduction of labor intensity in the program of production of a hotel and restaurant product the reasons of change of norms of labor costs are studied.

The materials of the analysis allow us to draw a conclusion about the implementation of technical, technological, organizational and other measures to reduce labor costs. Analysis of changes in the complexity of the program of production of hotel and restaurant product should be carried out in the areas presented in Figure 2. According to Figure 2, the directions of the reasons of change of complexity and revision of norms on the above-stated factors, it is expedient to open and present:

- firstly, constructive changes: 1) changes in technological documentation; 2) introduction of an innovative hotel and restaurant product and exclusion of a previously used service or technological operation; 3) change in the composition or range of the final product; 4) unification of the product;

- secondly, technological changes: 1) automation and informatization of the process of production of hotel and restaurant product; 2) introduction of new equipment; 3) modernization or a new way of using existing equipment; 4) technology adjustment; 5) change of technological routes;

- thirdly, improving the organization of production and labor: 1) the organization of parallel processes of providing a comprehensive service; 2) the

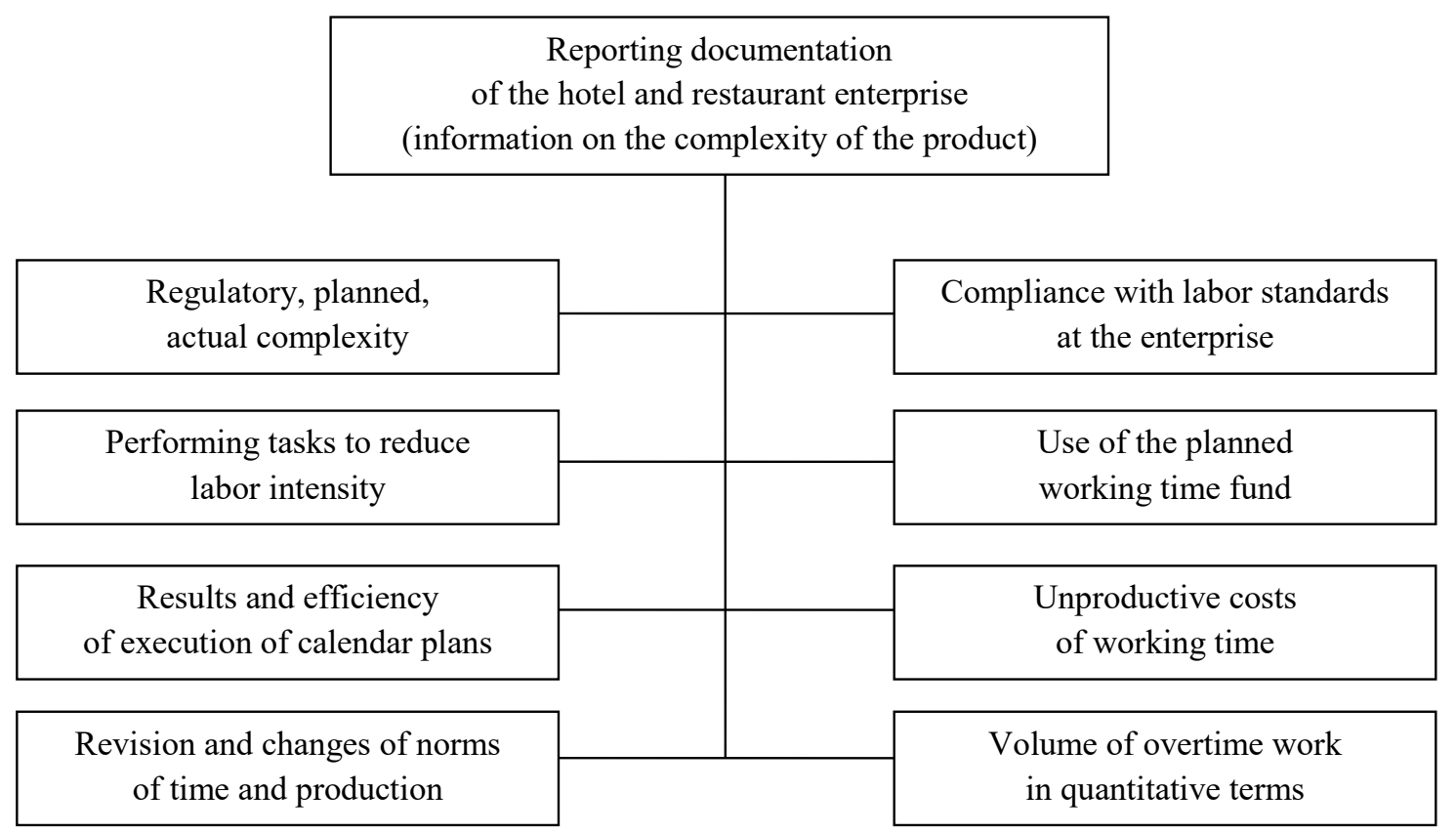

Figure 1. The structure of the content of the reporting documentation of the hotel and restaurant company

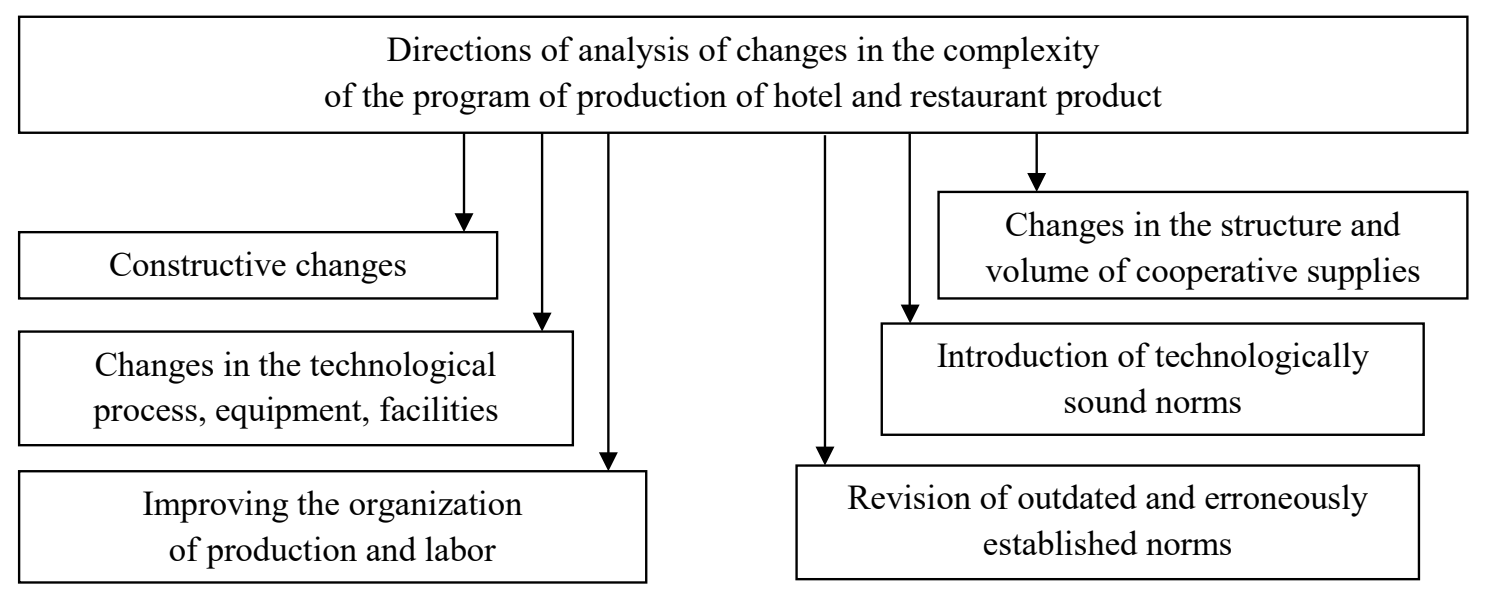

Figure 2. Areas of analysis of changes in the complexity of the program of production of hotel and restaurant product 
development of a team form of labor organization; 3) optimization of the organization of service of workplaces; 4) organization of customer service production lines; 5) kinship and combination of professions and key competencies of staff; 6) improvement of operational planning of hotel and restaurant product; 7) implementation of measures to increase the coefficient of variability and loading of equipment; 8) replacement of research and statistical standards with technologically sound ones;

- fourthly, change of the system of cooperation: 1) change of purchased semi-finished products, printing, etc., products of own production; 2) change of own products of semi-finished products, polygraphy, other purchased products;

- fifthly, the introduction of technologically sound standards (introduction of technology-based standards instead of research-statistical or technology-based standards that previously operated within the company);

- sixthly, revision of outdated and erroneously established norms as a result of untimely adjustment of normative documentation, significant moral aging of norms due to significant growth of qualification and skills of executors.

In order to identify reserves to reduce the complexity of the hotel and restaurant business, it is advisable to monitor and analyze the complexity of a particular product or service. From this point of view, it makes sense to distinguish three groups of reserves to increase productivity: reserves to reduce the complexity of the product; reserves for the use of working time; reserves for the rational use of personnel (Figure 3).

We will add that at the decision of a strategic task of achievement of an optimum level of labor productivity, the priority should be made on reserves of decrease in complexity of hotel and restaurant product for the reason that, on the one hand, reserves of use of working time fund according to the service concept are limited by duration of the working day established by the legislation and number of working days a year, and, on the other hand, the reserves for the rational use of personnel in the technological cycle are limited by the level of qualification of employees and physiologically acceptable labor intensity. That is, the reserves of the last two groups are ancillary. However, it is worth emphasizing that under the conditions of their effective use, labor productivity increases, but due to objective limitations these sources should not be considered as the main ones for critical acceleration of labor productivity growth in the future.

Of course, the main source of reserves to reduce the complexity of the hotel and restaurant product is scientific and technological progress, rapid development of the technological structure of the industry and digitalization of business processes, which, in turn, is the result of interaction of scientific, design, technological, supply and marketing firms, technology parks and business incubators, IT companies, spatial structures of business organization, virtual agencies, teams of hotel and restaurant companies and other service companies. In general, the pace of scientific and technological progress, the effectiveness of its latest and innovative achievements in the production of hotel and restaurant product are largely determined by the level and manufacturability of the hotel and restaurant product in the industry, quality management, effectiveness of material and moral incentives in domestic personnel management companies.

The authors consider it necessary to identify the factors influencing the formation of reserves to reduce the complexity of the hotel and restaurant product:

- growth of technological level of the product: increase of manufacturability, increase of qualitative characteristics, unification or standardization of elements of the complex product (technological operations), reduction of time for service, decrease in material consumption of a restaurant product, replacement of traditional materials by new and more economic in a hotel product;

- complex automation of production of hotel and restaurant product: mechanization of "manual" works, increase of level of automation of technological, cargo and transport equipment, control and measuring devices, computer equipment and means of IT management, replacement of the dispersed units of technological equipment by systems of interdependent cars and devices which operate in streaming online-mode, the use of robots, automatic manipulators, conveyors, the use of modern smart-equipment, hand-held wireless tools, automation of information processing operations;

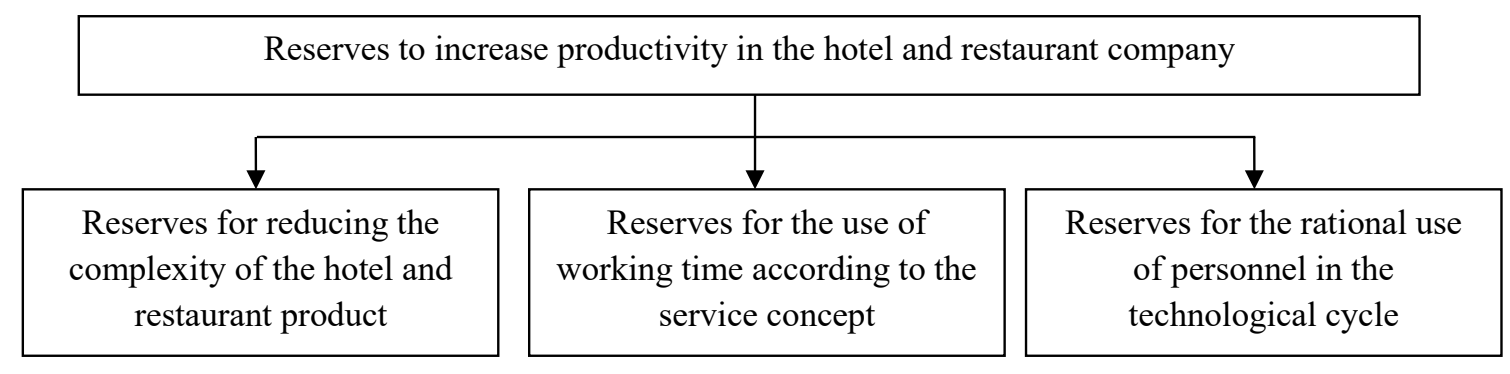

Figure 3. Reserves to increase productivity in the hotel and restaurant company (proposed by the authors) 
- improvement of technological processes: creation of flexible technological systems on the basis of smart-equipment with modern software and possibilities of equipment management in on- and offline modes; use of reliable smart-tools, mobile devices and peripherals, introduction of high-speed modes of personal data processing and digital-technologies of secure information storage; application of the ecological methods of production of hotel and restaurant product; extensive use of external business initiatives in business processes;

- improving the organization of labor: the development of team form; combination of professions, parallel complementary service processes; introduction of regulated active preventive maintenance of workplaces; comprehensive rationalization of jobs; improvement of rationing and remuneration systems, motivation and incentives;

- improvement of management and organization of production of hotel and restaurant product: creation of highly organized virtual informational, scientific and technological associations; improvement of planning, synchronization of balance of planned tasks with potential of labor resources, development of specialization, increase of flow and continuity level of processes.

In general, the reserves for reducing the complexity of the hotel and restaurant product objectively exist and are continuously reproduced at each enterprise. The task of the company's management is to identify these reserves in a timely manner and use them to further steadily increase productivity, which should be continuously monitored and develop organizational and technological measures that should be aimed at meeting the planned objectives of reducing labor intensity. It is right to recognize the fact that only with a clear interaction of technological, economic, marketing departments of the enterprise, a skillful combination of administrative influence, material and moral incentives for staff reserves to reduce the complexity of hotel and restaurant product become a real optimization and cost savings. Reserves for reducing the complexity of the hotel and restaurant product in the context of the COVID-19 pandemic, as a global industry factor in reducing the level of competitiveness, should be quantified living and tangible labor costs to be identified in the early stages of the life cycle of each item in a range of products and services as well as in the process of customer service through functional and cost analysis, economic and mathematical modeling, software, etc. Undoubtedly, the priority for any company is the introduction of an innovative hotel and restaurant product, to analyze the cost structure for its development and implementation should use adequate and modern methods of collecting, processing and using information.

Under any circumstances, the result of such an economic analysis should always be a reduction in unit costs, namely:
- growth of consumer qualities and benefits of customers from the purchase of hotel and restaurant product while reducing the cost of it;

- growth of these qualities at "economical" increase in expenses;

- cost reduction while maintaining or reasonably reducing the functional parameters of the product to a given level.

The reserves for labor intensity to be identified during the analysis are found by eliminating the excessive costs that were inherent in the imperfection of the hotel and restaurant product, as a whole, or its individual components, the obsolescence of technology and organization of the service process. The main attention should be paid to the identification of uneconomical technological solutions, generally unnecessary, redundant or irrationally used functional resources (excessive quality of service, expensive equipment, etc.), deviations from the basic conditions provided by the production processes of hotel and restaurant product. Reduction of excessive labor costs or their complete elimination should be performed within the fundamental technology of production of a complex hotel and restaurant product, assuming changes only in individual elements and maintaining the relationship of such elements, as well as their interaction with other components within the process.

First of all, a detailed analysis of the complexity of the hotel and restaurant product should be conducted to reduce the cost, especially those services that occupy the largest share in the overall complex product of the company while maintaining its supply to consumers in the future.

After selecting the objects of analysis, it is recommended to make a plan, which must include the following stages: 1) analysis of the collected information; 2) analysis of the technological process and the specifics of customer service, which allows you to identify tasks to reduce costs in the structure of their cost; 3) search for innovative ideas for solving priority tasks; 4) selection of the optimal of alternative ideas, examination, selection of rational recommendations and preparation for implementation; 5) making management decisions and ensuring their implementation. It should be borne in mind that the identification of ways to reduce labor intensity is facilitated by the analysis of the cost structure of the hotel and restaurant product based on the grouping of costs by different classification criteria depending on the system objectives in the company's management. Thus, the largest share in the cost of hotel and restaurant product is the cost of human resources, so the method of their analysis should be given special attention. In this case, the results of retrospective cost analysis are the basis for determining the planned cost of the product.

Thus, the introduction of the considered reserves to reduce the complexity of the hotel and restaurant product and cost accounting approaches allows to influence the reduction of their cost in the early 
stages of development of competitive services, which will increase the company's overall profit. Thus, the optimal use of human resources aims to maximize the return on investment in human capital.

Conclusions from the study. The basic reserve for increasing the profitability of the hotel and restaurant product is to reduce the cost by reducing its complexity in the personnel management system of service companies. The complexity of the product of enterprises in this industry is influenced by the organizational and technological level of the management system. It is clear that due to high financial costs it is impossible to adapt the production and technological system in a short period of time and change its organizational and technological level in order to reduce the complexity of the final product. However, the realities of the modern coronavirus economy require domestic hotel and restaurant companies to act on the priority of operational planning and implementation of shortterm measures. Therefore, the management of enterprises requires the development of priority planned organizational and technological measures, which are confirmed by quantitatively justified values of the operational effect of their implementation.

It is stated that today, most domestic companies for the production of hotel and restaurant products have a lack of sound plans for organizational and technological measures to improve production, in particular, aimed at reducing the complexity of the final product. In order to determine the plans of organizational and technological measures of management it is recommended: to determine the factors of organizational and technological level, which have a significant impact on the complexity of production of the product of the hotel and restaurant business; determine the numerical values of these factors; assess the degree of interrelation of indicators of organizational and technological level and complexity of production of hotel and restaurant product; to develop a mathematical model for determining the complexity of product production on the basis of organizational and technological level of the production system; make a plan of organizational and technological measures to reduce the complexity of manufacturing the product; to develop and implement an optimization model of minimizing the complexity of the production of hotel and restaurant product in the personnel management system on the basis of the concept of customer service.

It is clear that the preparation of organizational and technological measures of the enterprise should be based on product production in the current and subsequent periods, so to compile them it is necessary to determine the estimated complexity of hotel and restaurant product at the stage of deciding to include it in the range as a complex product.
It should be recognized that this article does not contain a list of all possible reserves and there are alternative and promising reserves to reduce the complexity of the hotel and restaurant product. Thus, the digitalization of the business of hotel and restaurant businesses is a critical condition for the safe existence of the enterprise. The solution of this problem should become a direction of further scientific research and a sphere of application of efforts of scientists.

\section{REFERENCES:}

1. Babenko A., Bolduieva O., Vasilichev D., Trifonov G. (2010) Menedzhment produktivností [Productivity management]. Zaporízhzhia: ZNTU. (in Ukrainian)

2. Borshchevskiy I., Trukhov V. (1988) Proizvoditel'nost' truda: metody analiza i prognozirovaniya [Productivity: methods of analysis and forecasting]. Minsk: Nauka. (in Russian)

3. Fedorov S., Arteyeva I. (1987) Sovershenstvovaniye planirovaniya snizheniya trudovykh zatrat $v$ usloviyakh intensivnogo proizvodstva [Improving planning to reduce labor costs in intensive production]. Leninhrad: LDNTP. (in Russian)

4. Frenkel' A. A. (1984) Proizvoditel'nost' truda: problemy modelirovaniya rosta [Labor productivity: problems of growth modeling.]. Moscow: Ekonomika. (in Russian)

5. Danyuk V., Kolot A. (1983) Organizatsiya mekhanizma upravleniya trudoyemkost'yu promyshlennoy produktsii [Organization of the mechanism of management of labor intensity of industrial production]. Kyiv. (in Russian)

6. Galena A., Danyuk V., Kolot A. (1987) Puti dostizheniya proyektnoy trudoyemkosti promyshlennoy produktsii [Ways to achieve the design labor intensity of industrial products]. Kyiv: Tekhníka. (in Russian)

7. Tsviliy S. M., Vasilichev D. V. (2011) Doslidzhennya faktoriv vplivu na trudomistkist' produktsii avtomobilebudivnikh pidpriiemstv Zaporiz'kogo regionu [Research of factors of influence on labor intensity of production of the automobile enterprises of the Zaporizhzhia region]. Strategiya i mekhanizmi regulyuvannya promislovogo rozvitku. Kontseptsiya sotsial'no-yekonomichnogo rozvitku regioniv v umovakh viklikiv globalizatsii - Strategy and mechanisms for regulating industrial development, vol. 3, pp. 448-457.

8. Zaitseva V. M. (ed.) (2017) Industriya gostinnosti v Ukraini: stan i tendentsii rozvitku [Hospitality industry in Ukraine]. Zaporizhzhia: Prosvita. (in Ukrainian)

9. Zaitseva V. M. (ed.) (2018) Strategichne upravlinnya hotel'nymy pidpriiemstvami $v$ umovakh globalizatsii [Strategic management of hotel enterprises in the context of globalization]. Zaporizhzhia: ZNTU. (in Ukrainian)

10. Kuklina T. S., Korniienko O. M. (2019) Mizhnarodniy gotel'niy biznes: problemi ta perspektivi [International hotel business: problems and prospects]. Infrastruktura rynku, 31. Availbale at: http://www.market-infr.od.ual journals/2019/31_2019_ukr/6.pdf (accessed 23 September 2020). 